\title{
Investment Governance: Delegation Decision Antecedents by Insurance Companies in Kenya
}

\author{
Rogers Kinoti M'Ariba, (MA (Econ), \\ CPA (K), CPS (K), PhD Candidate \\ Dr. Oluoch Oluoch, PhD, Senior Lecturer,
}

Jomo Kenyatta University of Agriculture and Technology, Nairobi, Kenya

Doi:10.19044/esj.2020.v16n13p286 URL:http://dx.doi.org/10.19044/esj.2020.v16n13p286

\begin{abstract}
Delegation decisions comprise a key component of investment governance structures of firms. Based on agency theory, this paper explores corporate governance and market dynamics as antecedents of investment management delegation by insurance firms in Kenya. Investment governance structures employed by firms are shaped by their unique circumstances and diverse considerations. The objectives of this research were to establish the influence of corporate governance and market dynamics on the investment governance structures of insurance firms in Kenya. The study adopted a descriptive approach with a target population of forty six firms in insurance and reinsurance business in Kenya. Both primary data and secondary data were collected. Data analysis was conducted using STATA relying on a binary logistic regression model. The study found that shareholder control, board diversity and avoidance of agency problems leads firms towards delegating their investment management activities. Desire to access alternative assets, peer influences and asset allocation considerations had a lesser extent of influence on firms towards delegation. The study concludes that large shareholder dictations and lack of investment management expertise in boards causes firms to adopt delegation models in their investment management. On the other hand, easy access to investment markets and constant supply of high yielding government bonds pulls firms towards internal investment management. It is recommended that firms make appropriate choices on extent of delegation by carefully evaluating their needs and developing structures that deliver best outcomes.
\end{abstract}

Keywords: Human- Investment management, delegation, agency theory, corporate governance, investment markets 


\section{Introduction}

The investment governance structures adopted by an institutional investor have implications in investment decision making and the overall investment strategy of the investor. Drew and Walk (2019) define investment governance as the effective use of resources by a fiduciary or agent seeking to fulfill a fiduciary duty to a principal (or beneficiary). Useem and Mitchell (2000) described investor governance as the structure of an investor's board, together with the complex of rules and practices that guide its oversight over the fund assets. Investment governance guides the overall investment management framework. Gordon, Sharpe and Bailey (2001) describe investment management as the process of managing money which may be passive or active, use explicit or implicit procedures and have risk level that is controlled or uncontrolled. It is the art and science of analyzing, selecting, maintaining and evaluating the performance of a collection of securities with the objective of achieving set investment goals.

Drew and Walk (2019) posit that investment governance of an investor may be dictated by legal and regulatory requirements or it may be a discretionary decision of the investor. In all cases, there are certain decision antecedents that must be put into consideration when making this decision. Hodgson et al. (2000) argue when deciding on their investment governance structures investors generally face both financial and non-financial constraints. Financial constraints include fund size, investment manager fees, target returns and risk appetite. Non- financial factors may be implicit costs such as investor's time available to manage the investment arrangements, accountability needs as a fiduciary or legislative requirements. There is no regulatory framework governing the investment governance of insurance companies in Kenya thereby leaving the decision at the discretion of the individual firms.

As institutional investors, insurance companies occupy a high place in terms of their Assets under Management (AUM). While accurate up to date global insurance statistics are difficult to obtain, available data shows that the insurance industry investment portfolios doubled from US \$10.4 trillion in 2000 accounting for $45.6 \%$ of global GDP to US \$ 20 trillion accounting for $57.7 \%$ of global GDP in 2009. This makes the insurance industry one of the largest players in the financial markets. In 2009, insurance companies controlled about $33 \%$ of total asset a decline from $37 \%$ in 1995 . The US was the largest holder of assets under management in 2009 controlling $45 \%$ of assets, having recorded a decline of $3 \%$ since 1995 (IMF, 2011). The insurance industry in Kenya had gross premium income of KShs. 253 billion (US \$ 2.53 billion) in 2019 up from KShs. 215 billion (US \$ 2.15 billion) in 2018 (IRA, 2020). The combined investment portfolios were worth KShs705 billion (US $\$ 7.05$ billion). 
The investment governance of an investor is defined by the investment management decision making structure and the investment management style. It is the system of decision making and oversight used to invest funds. The focal point of the any governance arrangement must be the fund. It comprises of fiduciaries who include the board and management who are responsible for high level decisions (Governance organ) and implementation teams that may be internal or external experts (Hodgson et al. 2000). The OECD Pension Funds Governance Guidelines lay down two broad components of the investment governance of a pension, namely, governance structure and governance mechanisms, all of which are equally applicable to insurance company settings (OECD, 2009). The governance framework establishes the investment management style which is characterized by passive or active management approaches and the extent of delegation.

The ultimate objective of governance arrangements is to protect the interests of the beneficiaries of the fund. However, the benefactors or contributors of the capital are also desirous of ensuring the funds contributed are invested prudently. In the case of an insurance company, the contributors of funds are also the beneficiaries. The shareholders of the companies have a residue interest in the operations of the company. The fiduciaries are the management board supported by the executive who may then use internal or external investment managers to invest the policy holder funds. Figure I highlights the generalized governance framework for an insurance firm.

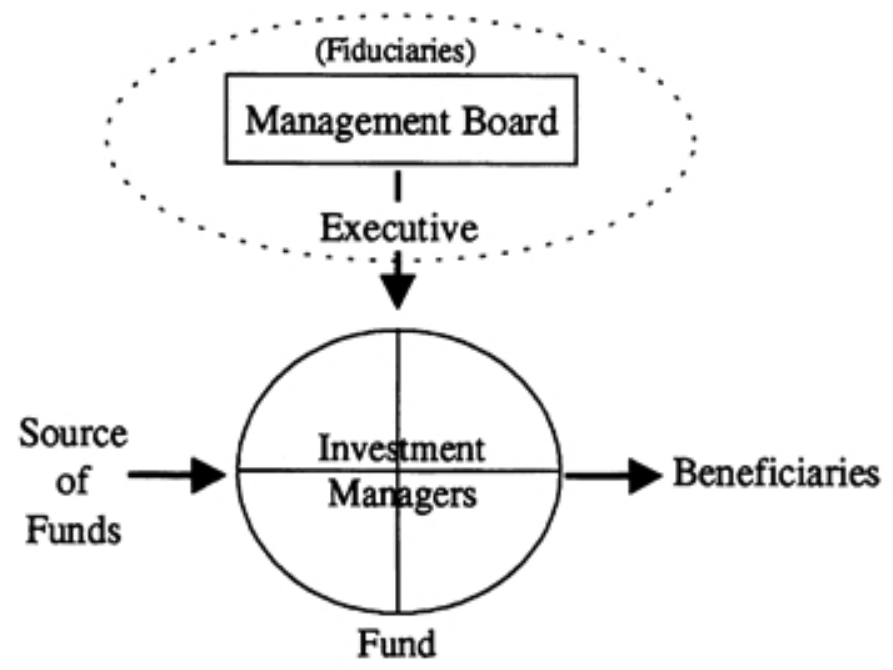

Figure I: Generalized Investment Governance Framework. Adapted from Hodgson et al. (2000) 
The insurance industry in Kenya comprises of 67 companies operating as general insurers, life insurers and reinsurers. In some cases, insurance holding companies control both life and general insurance subsidiaries following changes in the law to disallow composite insurance companies. There were thirty seven (37) general insurance companies, twenty five (25) life assurance companies and five (5) reinsurance companies registered to underwrite business in Kenya as at $31^{\text {st }}$ December 2019. The industry had a combined asset portfolio of KShs. 705.8 billion (US \$ 7.05 billion) representing about 7\% of Kenya's Gross Domestic Product (IRA, 2020). The governance arrangements around these assets are diverse and unregulated meaning that specific firm decisions determine the arrangements that are in place.

Delegated investment management exists where the investor uses an external manager to make investment decisions and implement them (Leung, 2015). Delegated investment management may take two forms: centralized or decentralized. An investor can decide to use a single manager to execute her investment management strategy. This constitutes centralization. Alternatively, different managers can be retained to oversee different asset class strategies. This constitutes decentralization (Leung, 2015). The managers selected for a delegated investment management structure can be generalists (balanced strategists) who have skill sets covering all the major asset classes and can therefore manage diversified portfolios. Specialist managers on the other hand, handle only certain asset classes and usually will not manage diversified portfolios.

Investment management delegation structures can also be distinguished in terms of how client funds are handled. In this case, we have two alternative arrangements: mutual funds and segregated funds also known as Separately Managed Accounts (SMAs). The two arrangements are similar in that both products are managed by professional money managers. They are however different in terms of the ownership of the underlying securities in the portfolio. In a mutual fund structure, the securities are owned by the fund which is managed as a single portfolio and its shares are in turn held by the investors. In SMAs, the investor owns the underlying securities in his or her own account and accounts are managed on a client-by-client basis (Peterson, Iachini \& Lam, 2011). In this study, a firm using any form of delegation to manage more than half of its assets is considered to be using the delegated investment management structure.

In Kenya investment management delegation is a common practice albeit not fully entrenched. This is because there is no regulatory requirement for firms to outsource their investment management activities. Being a crucial part of the investment governance structures, many firms have opted to set up captive fund management entities to which their investment assets are 
delegated. This form of internal delegation has been observed to have some pitfalls such as override of decisional independence of the fund manager by the insurance client due to their shareholding control (M'Ariba, 2018).

\section{Statement of the Problem}

Investment governance is an emerging area of focus for most institutional investors. Drew and Walk (2019) contend that investment governance is an enabler of stewardship that is expected of fiduciaries out to fulfill a duty to their principal. Investment governance relevance to insurance companies is amplified by the weight of assets that these entities control and their effects on the entire financial system. Increasingly, financial stewards are being held to a high standard of behavior by stakeholders and regulators. This makes investment governance a matter of great interest to industry practitioners, regulators and academia.

Globally, insurance companies rely heavily on their investment portfolios to meet their promises to policyholders. As such, Insurance companies are large investors in the financial markets all over the world (Schich, 2009). They intermediate more than 25\% of global assets under management (IMF, 2011). Therefore, the investment governance arrangements put in place by an insurance firm have implications for the policyholders and residually the shareholders of the company. As an unregulated activity in Kenya, investment management by insurance company as well as the governance arrangements around are at the discretion of the company. Companies have a variety of governance arrangements around their portfolio management operations.

A number of studies have explored the issue of investment governance from different stand points. Binsbergen, Brandt and Koijen (2008) studied the institutional investment delegation problem with a centralized Chief Investment Officer (CIO) and delegated management and concluded that uncertainty on risk appetite of delegated managers increases the costs of delegation. Useem and Mitchell (2000) study of US public and local authorities' retirement schemes reported that governance policies impacted investment decision and strategies. Coronado, Engen and Knight (2003) comparative study of the effects of governance structures of public and private pension schemes found that public schemes were prone to some political interference that sometimes led to a return sacrifice. There is little or no empirical output covering investment governance of insurance companies and more particularly their delegation considerations.

Investment governance of an investor has two components: governance structure and governance mechanisms. It is unwieldy to attempt to study all the elements together. This study focuses on governance structures 
and specifically addresses antecedents of delegation and expert advice acquisition.

\section{Objectives of the Study}

This study aims to address the following objectives:

\section{General Objective}

To explore investment governance structures of insurance companies in Kenya.

\section{Specific Objectives}

The following are the specific objectives of the study:

1. To ascertain the effect of corporate governance on delegation choices of insurance companies in Kenya.

2. To evaluate the significance of market dynamics on delegation choices of insurance companies in Kenya.

\section{Research Hypothesis}

Ho1: Corporate governance considerations do not affect delegation choices of insurance companies in Kenya.

Ho2: Market dynamics do not affect delegation choices of insurance companies in Kenya.

\section{Scope of the Study}

The research was confined to the Kenyan geographical area. The research universe comprised of forty six (46) insurance and reinsurance companies operating in Kenya. The sample was restricted to licensed firms that were in operation in 2017. According to IRA (2018), as at $31^{\text {st }}$ December 2017, there were twenty (20) composite insurers underwriting both general and life business, seventeen (17) companies were underwriting only general insurance business, six (6) companies were in life assurance business only while three (3) companies were composite reinsurance companies.

\section{Theoretical and Empirical Review} Agency Theory: Broken Agency

Golec (1992) characterizes the investor-investment manager relationship as one in which the investor (principal) hires an investment manager (agent) to offer investment management services. The services contracted for include information search, portfolio construction, trading and portfolio maintenance, all of which are unobservable in the portfolio return (output). Clark and Monk (2012) explain that, in institutional investment management, broken agency arises as a result of misalignment of interests due 
to inappropriate distribution of risks and expected returns between the investor (principal) and the investment manager (agent). The consequences of broken agency according to Clark and Monk (2012) include distortion of portfolio construction (asset allocation) and inappropriate performance measurement and benchmarking. The broken agency problem manifests on the investor in terms of poor investment performance and higher costs of management which are investment efficiency effects. These effects observable to external parties leading peer validation and emergence of avoidance of regret which are market based dynamics.

Spitzeck and Hansen (2010) argue that the objective of corporate governance has been traditionally conceptualized based on the agency theory as the maximization of shareholder value. While corporate governance is concerned mostly with how organizations are directed and controlled, this study is interested in isolating the effect that corporate governance arrangements have on decisions regarding the investment governance structures. Shleifer and Vishny (1986) conceptualization of large shareholder monitoring over management is based on agency theory. Similarly, board control and avoidance of agency costs are drawn directly from the theory.

Investment management delegation necessarily creates a chain of principals and agents. Hodgson et al. (2000) illustrates that for most funds, there are many principal - agent relationships. The providers of funds delegate management to a fiduciary who in turn appoints a professional investment manager to invest the assets. Therefore, the first principal is the provider of funds, and the fiduciary (trustee/executive) is the agent. The fiduciary, acting as new principal then acquires the professional services of an investment manager who is the agent. The beneficiaries of the investment funds may be the same as the providers of the funds or not. Clark and Monk (2012) contend that in institutional investment management, agency theory and particularly, broken agency, may explain the shift towards in-house investment management structure as investors seek to align risk and return through inhouse teams of professionals.

The choice between internal and delegated investment management is mostly on agency problems considerations. Outsourcing involves the engagement of an agent to perform a task on behalf of the principal. In house management is motivated by avoidance of agency relationships and associated costs. On the whole, agency theory offers strong explanatory power in the conceptualization of this study. 


\section{Conceptual Framework}

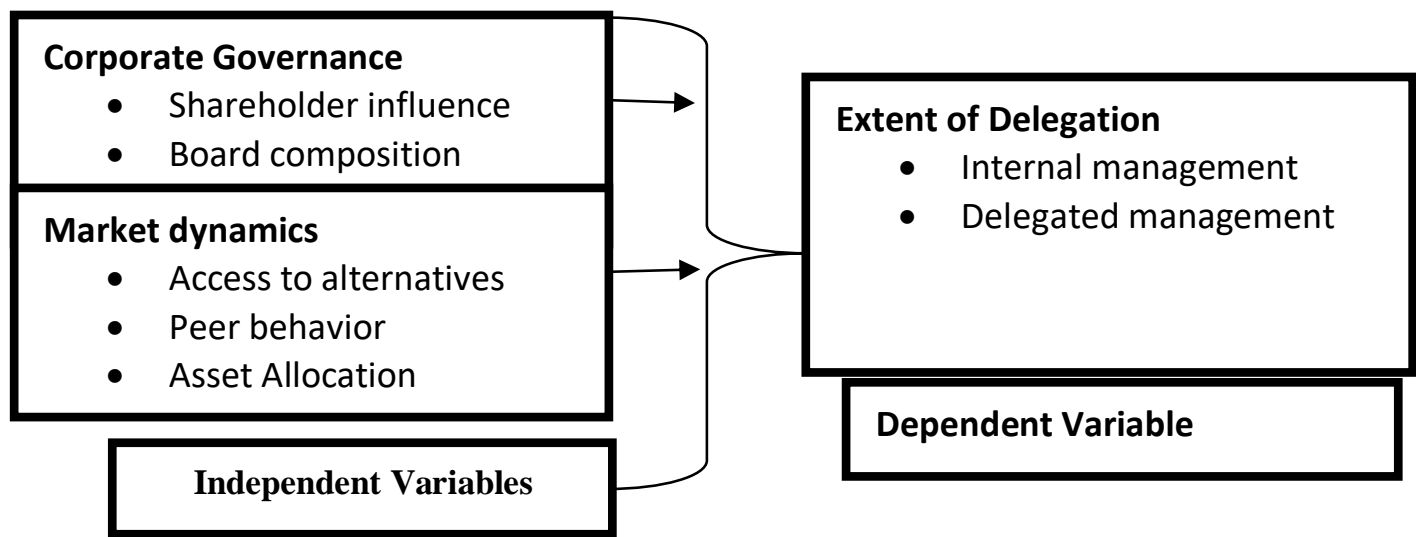

Figure II: Conceptual Framework.

Shleifer and Vishny (1986) contend that the management of a firm needs constant monitoring through persuasion and guidance. This monitoring role is played by the large shareholder. Large shareholders are a common occurrence in the Kenyan insurance sector. The main large shareholders are large multinational financial services groups, families and family holding companies and institutional investors like pension funds, investment companies and private equity funds. The nature of the large shareholder is likely to have an effect on key policy decisions. Shareholders control from multinational groups manifests in terms of deployment of international operational practices and group norms. Families reign their influence by taking strategic board positions to oversee management while institutional investors will often monitor management through professional and analyst pressure. This study considers five main large shareholder categories: local individuals, local holding company, family business, foreign multinationals, and state owned companies.

Boards of directors play significant monitoring roles with regards to firm performance (Wang, Jeng \& Peng, 2007). The effectiveness of a board of directors in executing its control and advisory roles is partly dependent on its composition in terms of size, diversity and balance (AICD, 2016). This research sought to find out the extent which board size and diversity influences the extent of delegation by insurance companies in Kenya. Board diversity was measured by gender and skills set.

The principal agent model has been used to describe a wide array of specific situations of economic exchange. Some examples of these relationships and interactions in finance include shareholder-manager, issuerinvestment banker and investor-investment advisor (Golec, 1992). The principal agent relationships are often fraught by conflicts of interest that breed 
principal agent problems or broken agency. According to Shah (2014), the presence of principal agent problems necessarily compounds the agency costs. In additional to the agent's professional fees, the principal incurs some monitoring costs such as auditors and consultant fees. The fiduciary in an investment management arrangement, being an agent of the asset owners, may wish to avoid the costs and risks associated with delegating the delegated investment management authority. This avoidance of principal agent problem is likely to influence the use of delegation where fiduciaries choose to manage assets internally. Principal agent problems were evaluated by extent of prevalence of agency relationships in the business and reported cases of agency failure.

A market is a group of buyers and sellers of a particular good or service. The behavior of the buyers and sellers determine market outcomes (Mankiw, 2008). Market dynamics are the factors that influence the competitive structure of a market. The behavior of market participants is influenced and also influences the behavior of others. This study focuses on effect of three market dynamics indicators on the choice of investment management structure namely, access to alternative assets, peer group behavior "peer effects", and asset allocation.

Clark and Monk (2012) argue that certain investment markets and products such as alternative assets are easier to access under certain investment management structures such as internal management. Market access refers to the ease of getting certain goods or services from particular markets. Some markets experience direct and indirect barriers that hinder users from accessing them. These barriers could exist as a result of the nature of the good or service, user classifications or the market organization. Urwin, Breban, Hodgson and Hunt (2001) posit that the role of alternative assets is to provide returns above equities and /or risks below equities. The three principal asset classes that provide this mix of attributes are private equity, hedge funds and real estate. The proportion of assets invested in alternative asset classes is related to the extent of delegation.

Gallagher, Gapes and Warren (2016) explain that under the coinvestment and partnership models of in-house asset management, small and medium sized portfolios are able to access and directly invest in large-ticket unlisted assets such as property or infrastructure by "piggy backing" on external management input. This enhanced market access from external input is also an overriding factor for investors who choose to delegate their portfolio management activities. External management allows both small and large funds enjoy benefits of enhanced markets access by using investment management with broad geographical and asset class reach or exposure. The asset allocation to alternative assets is used to measure the market access aspect of this research. 
Bursztyn, Ederer, Ferman, and Yucht (2014) explain that people's choices often look like the choices made by those around them: they try to "keep up with the Joneses". Hodgson et al. (2000) argue that investment fiduciaries' decisions are under the constant scrutiny and external validation by among others, the sponsors, beneficiaries, regulators and the wider public. These fiduciaries therefore take decisions that minimize regret and can be brand driven as well as peer group influenced. Cambridge associates (2016) explain peer group risk is a consideration investors are taking into account when choosing to delegate. Peer influence was measured qualitatively in terms of how investors feel compelled to take an action similar to their peers in the market.

Sharpe (1992) defines asset allocation as the distribution of an investment portfolio among a number of major asset classes. It involves the division of the investment choices into broad categories and choosing exposure that the portfolio should take in any one category. The ability to construct a tailor made portfolio demonstrates the asset allocation flexibility offered by internal management when compared to delegated management. Hodgson et al. (2000) argues that delegation choices have to be consistent with the asset allocation decision. The asset allocation decision is expressed in terms of the actual debt, equity, alternatives and cash mix as reported in firm records.

\section{Methodology}

This study employed a descriptive research design. The target population consisted of the composite, life and general insurance and reinsurance companies licensed to offer services in Kenya by the Insurance Regulatory Authority (IRA) in 2017. There were a total of forty six (46) companies licensed to undertake insurance and reinsurance business in Kenya as at $31^{\text {st }}$ December 2017 (IRA, 2018). Data collection took place between April and August 2019. Primary data was collected directly from the respondents using a self-administered questionnaire. The key respondent per firm was either the Chief Finance Officer (CFO) or the Chief Investment Officer (CIO). Secondary data was collected from regulatory filings. The study employed a binary logistic regression model represented as:

Where;

$$
\operatorname{Logit}[\pi(D L)]=\beta_{0}+\beta_{1} C G+\beta_{2} M D+\varepsilon
$$

$\Pi(\mathrm{DL})=$ the probability of a firm choosing Delegation over internal management.

$\mathrm{CG} \quad=\quad$ the market dynamic factors

$\mathrm{MD} \quad=$ the corporate governance factors

$\beta_{0} \quad=$ the intercept representing the "baseline" event rate. 
$\beta_{1} \quad=\quad$ the odds ratio for corporate governance effect

$\beta_{2} \quad=$ the odds ratio (coefficient) for the market dynamics

effect

$\varepsilon_{0} \quad=\quad$ the error term

\section{Discussion of Results}

It was not known a priori the extent of use of delegation in the management of portfolios by insurance companies. Therefore, primary data was collected to find out the extent of delegation by firms in the industry. It was found that $66 \%$ of respondent firms used internal investment management teams while $34 \%$ of the firms used the delegation approach. Having established that more firms relied on internal management as opposed to delegation, the researchers set out to find out the factors that led firms to delegation and away from internal management. The primary data collected for this purpose was on a five point Likert scale to establish the influence that the conceptualized factors influenced the delegation decision. The subjective responses were backed up with secondary data. Based on the Likelihood Ratio test $\left(\mathrm{LR} \mathrm{chi}^{2}=16.43, \mathrm{p}=0.0025\right)$ the model is well fitted and both corporate governance and market dynamics are important factors influencing delegation choices. Table I presents the results from the logistic model from STATA.

Table I. Logistic Regression Model Results

\begin{tabular}{|c|c|c|c|c|c|c|}
\hline \multirow{2}{*}{\multicolumn{3}{|c|}{$\begin{array}{l}\text { Logistic Regression. } \\
\text { Log Likelihood }=-16.1955\end{array}$}} & \multicolumn{4}{|c|}{ Number of obs $=38$} \\
\hline & & & \multicolumn{2}{|c|}{$\begin{array}{l}\mathrm{LR}_{\mathrm{chi}^{2}}(2) \\
\text { Prob }>\mathrm{Chi}^{2} \\
\text { Pseudo } \mathrm{R}^{2}\end{array}$} & $\begin{array}{l}=16.43 \\
=0.0025 \\
=0.3366\end{array}$ & \\
\hline $\mathrm{A} 1 \mid$ & Odds Ratio & Std. Err. & $\mathrm{z}$ & $\mathrm{P}>|\mathrm{z}|$ & {$[95 \%$} & f. Int.] \\
\hline $\begin{array}{l}\text { Corporate } \\
\text { Governance }\end{array}$ & 1.2285 & 0.6605 & 0.100 & 0.017 & 0.2303 & 3.7437 \\
\hline Market Dynamics & 1.0500 & 4.8923 & 2.230 & 0.026 & 0.9240 & 9.5168 \\
\hline
\end{tabular}

The logistic regression modelling relied on odds ratio analysis. Corporate governance indicators had an odds ratio of 1.2285 which implies that unit increase in corporate governance indicators increases the chances of a firm choosing delegation over in house management by $22.85 \%$. This finding can be explained by the fact that as greater levels of corporate governance and surveillance are employed firms, are likely to move to delegating the management of their portfolios. 
The nature of the majority shareholder was noted to have moderate to high extent of influence on investment management structure decisions. Sixty percent of the respondent firms were privately owned and controlled by individual investors or locally incorporated holding companies. By their nature, private entities enjoy heavy patronage of the owners who control almost all critical decisions. Most individual investors in the Kenyan insurance sector have a strong professional background in insurance operations. As such they lack the requisite expertise in investment management. As a consequence, these individual investors have the inclination to outsource the management of their pool of funds to professional investment management firms. This partly explains the positive odds of firms delegating investment management over internal management.

The composition of a firm's board was found to have small to moderate extent of influence on investment management structure decisions. The respondent firms had average board size of eight members with an average of one female director. The majority of the directors were also professionals in strategic management (average of five) and insurance operations (average of two). The nature of board composition suggests the lack of expertise in finance and investment management further reinforcing the tendency to outsource investment management decisions.

The need to avoid agency problems was found to be have moderate to great extent of influence on investment management structure choice decisions. Most firms reported to be outsourcing legal services (53\%) and investment management (24\%). The main agency problems encountered were communication and reporting (44\%), fees and costs $(33 \%)$ and monitoring of the agents $(33 \%)$. Based on these observations, it would be imperative that the need to avoid agency costs supports internal management. As an individual factor, it exerts a negative pull against delegation.

To ascertain the efficacy of the model findings, the null hypothesis that corporate governance considerations do not affect delegation choices of insurance companies in Kenya was tested. The Wald test statistic for this null hypothesis was 5.01 and $p>\chi^{2}=0.017$. Based on the Wald statistic decision rule, at the $5 \%$ level of significance the null hypothesis was rejected because $\mathrm{p}>\chi^{2}<0.05$ and concluded that corporate governance factors significantly affect the delegation choices of insurance companies in Kenya.

Market dynamics had an odds ratio of 1.050. This means that a one unit increase in market dynamics factors increases the odds of a firm choosing delegation over in house management by $5.0 \%$. This means that while market dynamics is an important antecedent of investment governance structure choice, it is less powerful when it is compared to corporate governance considerations. 
In this analysis, market dynamics was operationalized by three sub variables namely, the need for greater access to alternative asset classes, peer group behavior and asset allocation effects. Access to alternative asset classes was observed to have a small to moderate extent of influence on decisions on investment management structure. It was also observed that ninety percent $(90 \%)$ of the respondents had invested in real estate as the main alternative asset class, forty percent (40\%) was accessing private equity investments while twenty (20\%) had invested in offshore investment assets. It can be safely concluded that real estate assets were an easy to access asset class among insurance companies in Kenya and was the main alternative asset class investment for most companies. No firms had invested in commodities, currencies and related derivatives. It is evident that alternative asset classes are easily accessing in the Kenyan market space and therefore is not a great influence for firms to delegate their portfolio management activities.

The behavior of peers was found to have a moderate extent of influence on delegation decisions. The interaction of board members and senior management with industry peers was considered as offering the best avenue for learning and observing the behavior of others. Ninety five (95\%) of respondent firm's board members and senior management had access to peers through membership in two main industry associations namely the Insurance Institute of Kenya and Association of Kenya Insurers. This means that interaction of companies' management at high level association meetings offered opportunities to learn the behavior of peers which was likely to alter the behavior of individual firms towards the herd.

Asset allocation had a great extent of influence on firm's decisions on investment management structures. The respondents' asset allocation was heavily skewed to debt with an allocation of fifty eight percent (58\%) of total assets and property investments that accounted for an average of thirty percent $(30 \%)$. The clustering of investments in debt was a result of the reliable supply of high yielding government and corporate debt in the Kenyan investment market space. The regulations by IRA also require at least $25 \%$ of insurance companies' portfolios to be invested in government securities as a mechanism of policy holders' funds protection since these securities are secure from credit default.

The null hypothesis that market dynamics do not influence firms' delegation choices was tested. The Wald test statistic for this null hypothesis was 4.96 and $p>\chi^{2}=0.026$. Based on the Wald statistic decision rule, at the $5 \%$ level of significance the null hypothesis was rejected since $\mathrm{p}>\chi^{2}<0.05$ leading to the conclusion that market dynamics significantly affect the delegation choices of insurance companies in Kenya. 


\section{Summary, Conclusions and Recommendations}

Investment governance structures are the bedrock of investment management stewardship and fiduciary duty. Insurance companies in Kenya use two main approaches to investment management. Internal management is more prevalent with sixty six percent $(66 \%)$ of the industry's firms managing their portfolios either through internal board investment committees, management investment committees or professional investment staff. Delegated investment management is used by thirty four percent $(34 \%)$ of the firms in the industry.

The investment governance structure of insurance firms is not regulated by the insurance regulator. Therefore each firm has discretion in the choice of how oversees the management of its assets and more so how it accesses external expertise and advise. Based on this study, corporate governance and market dynamics are statistically significant antecedents of firms' delegation choices. On corporate governance, it was found that large shareholders and family business owners sometimes dictate the delegation choices by requiring their firms to outsource their portfolio management to specific external experts. In other instances, the composition of the board increases the overall investment oversight amid lack of board skills thereby leading firms to delegate their portfolio management. On the other hand, the need to avoid agency problems leads firms towards internal management.

Market dynamics are an important factor in the delegation decision. To access alternative assets, sometimes firms turn to delegating their investment management activities. However, in Kenya, it is relatively easy to access alternative assets even with internal management and therefore access to alternative assets in not a great influence towards delegation. There are significant interactions among industry peers that sometimes lead firms to herd together. Therefore, peer group behavior exerts an influence for firms to internally manage their portfolio in line with the herd. The asset allocation of insurance firms is heavily skewed to assets that do not require high levels of skills to manage and are easily available. Asset allocation considerations therefore lead firm to manage assets internally. On the whole market dynamics are important but the extent of pull is more towards internal management as opposed to external delegation.

The findings from this study lead to the conclusion that the delegation choices of insurance firms in Kenya are greatly influenced by corporate governance considerations and to a lesser extent, market dynamics. Large shareholder control and lack of investment skills in boards leads firms to delegate portfolios. Easy access to investment markets and alternative assets amid constant supply of high yielding bonds as well peer influences lead firms towards managing assets internally. 
Based on the findings of this study, it is recommended firms should carefully evaluate their unique circumstances and market environment in designing their investment governance structures. Delegation structures should be preferred to internal management in cases where boards lack the robustness of skills as would be required to provide oversight in an internal investment management set up. Furthermore, due regard should be given to the market environment to avoid creating structures that do not yield incremental gains to the firm.

\section{References:}

1. Australian Institute of Company Directors (2016). Improving Board effectiveness: Board Performance. Director tools. Retrieved from ttps://aicd.companydirectors.com.au/-/media/cd2/resources/directorresources/director-tools/pdf

2. Bursztyn, L., Ederer, F., Ferman, B., \& Yuchtman, N. (2014). Understanding mechanisms underlying peer effects: evidence from a field experiment on financial decisions. Econometrica, 82(4), 12731301. Retrieved from http://www.jstor.org/stable/24029253

3. Cambridge associates (2016). How does an outsourced CIO (OCIO) relationship work? Accessed on 21.11.2016 from www.cambridgeassociates.com.

4. Clark, G. L., \& Monk, A. H. B. (2012). Principles and policies for inhouse asset management. SSRN Electronic Journal, 1-11. Accessed 8 September 2016. https://doi.org/10.2139/ssrn.2189650.

5. Drew, M.E. \& Walk, A.N. (2019). Investment Governance of Fiduciaries. CFA Institute Research Foundation, USA.

6. Gallagher, D. R., Gapes, T., \& Warren, G. (2016). In-house investment management: Making and implementing the decision. Centre for International Finance and Regulation, Working Paper no. 094/2016, Project No. F016.

7. Golec, J.H. (1992). Empirical tests of a principal-agent model of the investor-investment advisor relationship. The Journal of Financial and Quantitative Analysis, 27(1), 81-95. Retrieved from http://www.jstor.org/stable/2331299.

8. Gordon, A., Sharpe, W., \& Bailey, J. (2001). Fundamentals of investments. New Jersey: Prentice Hall.

9. Hodgson, T. M., Breban, S., Ford, C. L., Streatfield, M. P., \& Urwin, R. C. (2000). The concept of investment efficiency and its application to investment management structures. British Actuarial Journal, 6111(6), 451-545. Retrieved from http://www.jstor.org/stable/41141479

10. Insurance Regulatory Authority (2015). Insurance Industry Report 
2014. Nairobi, Kenya.

11. Insurance Regulatory Authority (2017). Insurance Industry Report 2016. Nairobi, Kenya.

12. Insurance Regulatory Authority (2018). Insurance Industry Report 2017. Nairobi, Kenya.

13. Insurance Regulatory Authority (2020). Insurance Industry Quarterly Statistics. Nairobi, Kenya.

14. International Monetary Fund (2011). Long term investors and their asset allocation: where are they now? Global Financial Stability Report, September 2011, 1-48.

15. Leung, R. C. W. (2015). Centralized versus decentralized delegated portfolio management under moral hazard (Unpublished paper). Department of finance, Haas school of business, University of California, Berkeley, USA.

16. M'Ariba, R.K. (2018). Investment management structures: An exploratory review of institutional investors in Kenya. International Journal of Economics, Business and Management Research, 2(3), 5771.

17. Mankiw, G.N. (2006). Principles of microeconomics. South Western: Cengage Learning

18. OECD (2009). OECD guidelines for pension fund governance. OECD Publishing.

19. Peterson, J. D., Iachini, M. J., \& Lam, W. (2011). Identifying characteristics to predict separately managed account performance. Financial Analysts Journal, 67(4), 30-40.

20. Schich, S. (2009). Insurance companies and the financial crisis. $O E C D$ journal: Financial Market Trends, 2009(2), 1-31. OECD Publishing.

21. Shah, S. N. (2014). The principal - agent problem in finance ( a summary ). CFA Institute Research Foundation, 1-8. Accessed 10 August 2016. https://doi.org/http://www.cfapubs.org/toc/rflr/2014/9/1.

22. Sharpe, W. (2011). Investors and markets: portfolio choices, asset prices and investment advice. New Jersey: Princeton University Press.

23. Sharpe, W. (1992). Asset allocation: management style and performance measurement. Journal of Portfolio Management, Winter 1992, 7-19.

24. Shleifer, A., \& Vishny, R.W. (1986). Large Shareholders and Corporate Control. Journal of Political Economy, 94(3), 461-488. Retrieved from http://www.jstor.org/stable/1833044

25. Spitzeck \& Hansen (2010). Stakeholder governance: how stakeholders influence corporate decision making. The international journal of business in society, 10(4), 378-391. Retrieved from 
https://doi.org/10.1108/14720701011069623

26. Urwin, R. C., Breban, S. J., Hodgson T. M. and Hunt, A. (2001). Risk budgeting in pension investment. British Actuarial Journal, 7(3), 319347.

27. Useem, M., \& Mitchell, O. S. (2000). Holders of the purse strings: Governance and performance of public retirement systems. Social Science Quarterly, 81(2), 489-506. Retrieved from http://www.jstor.org/stable/42863971

28. Wang, J.L., Jeng, V., \& Peng, J.L. (2007). The impact of corporate governance structure on the efficiency performance of insurance companies in Taiwan. The Geneva Papers on Risk and Insurance. Issues and Practice, 32(2), 264-282. Retrieved from http://www.jstor.org/stable/41952938. 